\title{
Spring staging of Eiders Somateria mollissima in some Swedish east coast archipelagos and at Gotland 2009 and 2010
}

\author{
Vårrastande ejdrar Somateria mollissima i några svenska ostkustskärgårdarna \\ samt vid Gotland 2009 och 2010
}

\section{LEIF NILSSON}

The Eider Somateria mollissima is a common breeding species in the Baltic. In 2008, Ottosson et al. (2012) estimated that the breeding population of Eiders in the archipelagoes of the four Swedish counties of Kalmar, Östergötland, Södermanland and Stockholm was in the order of 103000 pairs, whereas the breeding population around Gotland was about 6000 pairs. The distribution of breeding Eiders in several regions is well known from extensive surveys (cf. Gezelius 2012, Sveriges Ornitologiska Förening 2009). On the other hand, the distribution of staging Eiders in early spring has not been studied on a regional level before.

During 2009-2011, extensive offshore surveys were undertaken in the Baltic (Nilsson 2012, Skov et al. 2011). The main target species was the Longtailed Duck Clangula hyemalis. For various reasons some areas (the east coast archipelagos from Gävle-Kråkelund in 2009 and eastern Gotland in 2010) were surveyed during the time for the spring migration of the Eider (which is still winter for the Long-tailed Ducks, leaving the Baltic in May). In this short contribution I present the results from these surveys for the Eider to give first snapshots of the distribution of the species along the Baltic coast of Sweden during the migration period.

\section{Material and methods}

During three days in early spring 2009 (25 March 2 and 3 April) the main parts of the archipelagoes and offshore waters of the Swedish mainland coast from Gävle in the north to Kråkelund in Kalmar county in the south were covered by aerial surveys along fixed transects with a distance of 4 $\mathrm{km}$ between survey lines (Figure 1). There were no counts in a part of the Uppland coast (Väddö) due to military training not allowing aerial survey. Moreover the surveys of the vast Stockholm archipelago were concentrated to the central and outer parts due to the distribution of the main target species. The east coast of Gotland was surveyed on 14 April 2010, also with $4 \mathrm{~km}$ between the transects.

For the surveys a twin-engined CESSNA-337 Skymaster was used flying at an altitude of about
$70 \mathrm{~m}$ and at a speed of about 100 knots. Two observers were employed recording all birds within a sector of $200 \mathrm{~m}$ on each side of the aircraft. The survey belt is thus $320 \mathrm{~m}$ wide due to a blind angel just below the aircraft. Navigation was between fixed waypoints using the GPS of the aircraft, a separate GPS being used to track the actual flight. For further information on methods see Nilsson (2012).

\section{Results and discussion}

During the surveys in the mainland archipelagoes in spring 2009, a total of 12567 Eiders were counted in the main belt of the surveyed transects (Table 1). Taking the coverage into consideration this translates to an estimated total for all areas surveyed of 158000 Eiders (Correction factor 12.5; see Nilsson 2012). Of these birds, 90000 were estimated for the Stockholm archipelago but the actual number was certainly higher as the innermost parts of the archipelago were not covered by the surveys (Figure 1). In the other counties the coverage was nearly complete.

The Eider was distributed all along the coast from Kråkelund in the archipelago of Kalmar

Table 1. Number of Eiders Somateria mollissima counted along the survey lines in the archipelagos of the different counties together with estimated totals for the surveyed areas.

Antal inräknade ejdrar längs inventeringslinjerna i skärgårdarna i de olika länen tillsammans med uppskattat antal för de inventerade områdena.

\begin{tabular}{lrr}
\hline $\begin{array}{l}\text { County } \\
\text { Län }\end{array}$ & $\begin{array}{r}\text { Counted } \\
\text { Räknat }\end{array}$ & $\begin{array}{r}\text { Estimated } \\
\text { Skattat }\end{array}$ \\
\hline N Kalmar & 932 & 12000 \\
Östergötland & 1978 & 25000 \\
Södermanland & 1839 & 23000 \\
Stockholm & 7189 & 90000 \\
Uppsala & 629 & 8000 \\
\hline Total Summa & 12567 & 158000 \\
\hline
\end{tabular}




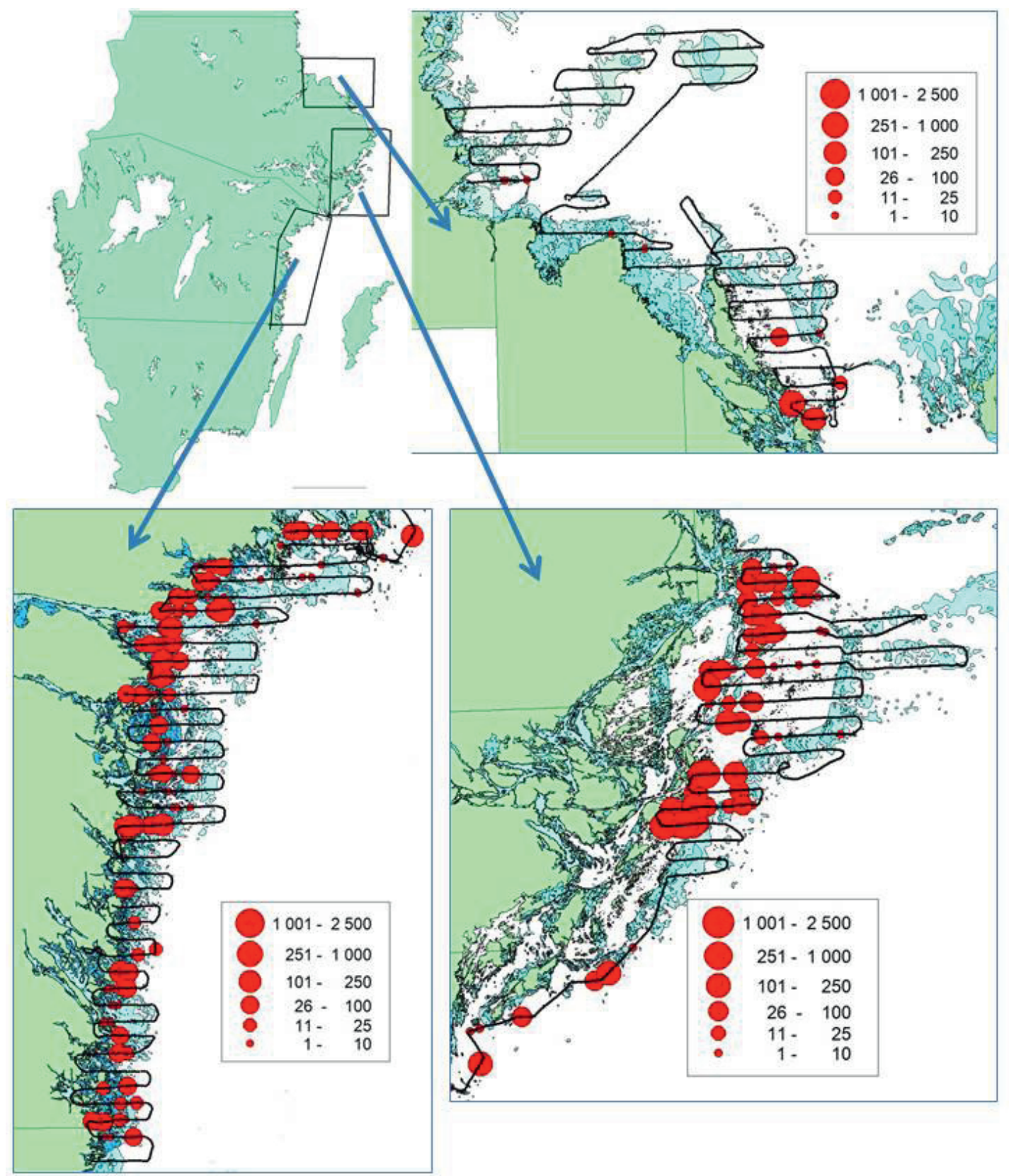

Figure 1.The distribution of staging Eiders Somateria mollissima in three east coast archipelagos in the spring of 2009. The dotted black lines show the actual flight paths during the surveys.

Utbredning av rastande ejdrar i tre ostkustskärgårdar våren 2009. De prickade linjerna anger flygrutterna. 
County (southern limit of the study area) to the coasts of Uppsala County. On the other hand almost no Eiders were found in the northernmost area surveyed, the Gävle Bight. In the Stockholm archipelago the Eiders were found in the central part of the archipelago, very few in the outer parts. In the other archipelagos that are not so wide, the Eiders were concentrated to the parts quite close to but outside the larger islands.

The distribution of staging Eiders in the Stockholm archipelago during the present spring survey was different from the distribution of breeding Eiders according to a survey of the same areas in 2000-2005 (Sveriges ornitologiska Förening 2009). The largest concentrations of breeding Eiders were found in the outer parts of the archipelago, whereas we found few staging staging birds in this part. The larger staging flocks were recorded close to the larger islands in the central part of the archipelago. The reasons for this pattern are not known. It is however important to bear in mind that just one survey is only a snapshot of the distri-

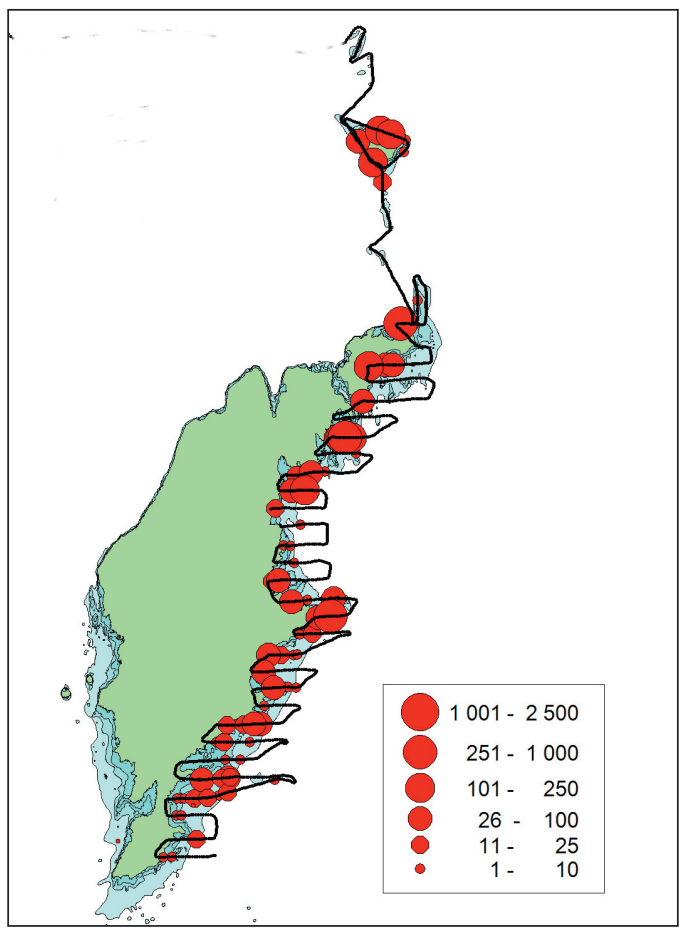

Figure 2. The distribution of staging Eiders Somateria mollissima along the east coast of Gotland on 14 April 2010. The dotted black lines show the actual flight paths during the surveys.

Utbredning av rastande ejdrar längs Gotlands ostkust 14 april 2010. De prickade linjerna anger flygrutterna. bution of the Eider that can be affected by several factors.

East of Gotland a total of 4705 Eiders were counted in the main belt during the survey in midApril 2010. This compares to an estimated total of about 60000 Eiders. In addition to these Eiders a number of Eiders use the western coast of Gotland bringing the total for the island even higher. This estimate should be compared with an estimate of 6000 breeding pairs on Gotland (Ottosson et al. 2012). It is apparent that a large proportion of the Eiders at Gotland were on migration further north, most probably to the important breeding areas in the Finnish archipelago.

It is well-known that there is a massive migration of Eiders in spring along the Swedish Baltic coast with large numbers passing along the mainland coast through the Kalmarsund. Radar studies (Alerstam et al. 1974) shows that there is a massive migration also east of Öland, probably aiming more directly to areas on the east coast of the Baltic. The staging of large numbers of Eiders on the coast of Gotland is fully in line with this picture.

\section{Acknowledgements}

The censuses were supported by grants from the Swedish Environmental Protection Agency.

\section{References}

Alerstam, T., Bauer, C.-A. \& Roos, G. 1974. Spring migration of Eiders Somateria mollissima in southern Scandinavia. Ibis 116: 194-210.

Gezelius, L. 2012. Kustfåglar i Östergötland-inventeringar 2007 och 2010. Länsstyrelsen i Östergötland Rapport 2012:7.

Nilsson, L. 2012. Distribution and numbers of wintering sea ducks in Swedish offshore waters. Ornis Svecica 22: 39-60.

Ottosson, U. Ottvall, R., Elmberg, J., Green, M., Gustafsson, E., Haas, F., Holmqvist, N., Lundström, A., Nilsson, L., Svensson, M., Svensson, S. \& Tjernberg, M. 2012. Fåglarna i Sverige - antal och förekomst. SOF, Halmstad.

Skov, H., Heinänen, S., Zydelis, R., Bellebaum, J., Bzoma, S., Dagys, M., Durinck, J., Garthe, S., Grishanov, G.,Hario, M., Kiekbusch, J.J., Kue, J., Kuresoo, A., Larsson, K., Luigujoe, L., Meissner, W., Nehls, H.W., Petersen, I.K., Roos, M.M., Pihl, S., Sonntag, N., Stock, A., Stipniece, A. \& Wahl. J. 2011. Waterbird Populations and Pressures in the Baltic Sea. Tema Nord 2011:550.

Sveriges Ornitologiska Förening. 2009. Kustfågelbeståndets utveckling $i$ Stockholms läns skärgård. 


\section{Sammanfattning}

Under 2009-2011 genomfördes omfattande flyginventeringar av sjöfågel i de svenska farvattnen för att kartlägga förekomsten av övervintrande sjöfåglar, med stark tonvikt på att kartlägga förekomsten av alfågel. Inventeringarna genomfördes på uppdrag av Naturvårdsverket och hade också som syfte att utarbeta metoder för utsjönventeringar av sjöfåglar. Inom ramen för undersökningarna genomfördes några inventeringar under ejderns flyttningsperiod: ostkustskärgårdarna (Figur 1) 25 mars - 3 april 2009 samt öster om Gotland (Figur 2) 14 april 2010. Eftersom regionala inventeringar av rastande ejdrar i de yttre havsområdena saknas ges här en kort presentation av resultaten från inventeringarna. Eftersom områdena bara inventerats vid ett tillfälle måste man beakta att de endast ger en ögonblicksbild av ejderförekomsten under våren $\mathrm{i}$ de aktuella områdena.

Ejdrarnas utbredning längs kusterna presenteras i kartor (Figur 1 och 2). När det gäller skärgårdarna visar ejdrarna en koncentration till zonen utanför de större öarna (observera att de inre delarna av Stockholms skärgård inte inventerats). Däremot saknas i stort sett ejdrar i den yttre delen av Stockholms skärgård, där man har en betydande koncentration av häckande ejdrar. Vid Gotland förekom ejdrar i flockar längs hela ostkusten samt vid Gotska Sandön.

I skärgårdsområdena räknades 12500 ejdrar, vilket motsvarar 158000 när man kompenserar för inventeringarnas täckningsgrad (Tabell 1). 90000 av de beräknade ejdrarna återfanns i Stockholms skärgård, där ytterligare ett betydande antal torde ha funnits i de icke-inventerade delarna. Utanför Gotland räknades 4705 ejdrar, vilket motsvarar ett skattat antal på ca 60000 , vilket är vida mer än den häckande populationen på ca 6000 par. Ett betydande antal ejdrar på flyttning mot Finland torde rastat vid Gotland.

Leif Nilsson, Department of Biology, Lund university, Ecology Building, S-223 62 Lund, Sweden,

E-mail: leif.nilsson@biol.lu.se 